\section{La ciudad como escuela}

\author{
Francisca Benítez Arquitecta, Universidad de Chile
}

¿Desde cuántos frentes los arquitectos podemos actuar en la ciudad? Esta experiencia de una chilena en Nueva York se detiene, antes que en el diseño de proyectos, en la construcción de un código comunicativo que permita el diálogo interesado y participativo entre arquitectos y los ciudadanos: en este caso, estudiantes de secundaria.

"Los estudiantes secundarios chilenos han hecho revivir un nuevo mayo como aqué de 1968 en París que estremeció a toda Europa. Cada cierto tiempo los jóvenes estudiantes ponen la nota.(...) Hoy la rebelión de los 'pingüinos' altera positivamente el apoltronamiento de todos. Por alguna parte tenía que estallar lo que estaba contenido por largos años. En hora buena ocurre esta catarsis que descoloca al gobierno, a los propios educadores, autoridades de todo tipo, a partidos políticos y a sindicatos. Todos han sido sobrepasados"1.

INTERSECCIONES, REDES Y SISTEMAS EDUCACIONALES PARASITARIOS / Nueva York, 31 de mayo de 2006. Mientras escribo estas líneas, miles de estudiantes a lo largo de todo Chile protagonizan una de las movilizaciones más extraordinarias que me ha tocado presenciar online. A pesar de su precocidad, estos jóvenes nos recuerdan esa promesa que vivimos haciéndonos como sociedad y nos dicen qué es urgente. ¿Cómo enfrentar esta demanda e iniciar el necesario cambio?

A pesar de la distancia y las diferencias que separan Brooklyn de Chile, me interesa ver los parentescos y apuntar a lo que los mismísimos escolares han demostrado en la organización de esta protesta nacional: el poder latente en la infraestructura ya existente, el uso de mecanismos ajenos al sistema de educación para vitalizar la educación misma y las implicancias de sistemas de redes y conexiones, más allá de Internet (y de vuelta al espacio concreto). En este sentido, experiencias como la superposición de programas educacionales de carácter práctico y experimental sobre el programa pedagógico existente, que utilizan la ciudad como texto de estudio, indican una posible participación de los arquitectos en estos procesos.

Desde 2001 colaboro con el Centro para Pedagogía Urbana (CUP) en distintos proyectos de educación, arte y arquitectura. Se trata de una organización independiente y sin fines de lucro, ubicada en Brooklyn, Nueva York. Sus cabecillas, Damon Rich y Rosten Woo, más una extensa y fluctuante red de colaboradores, se dedican a hacer "proyectos educacionales sobre lugares, y sobre cómo éstos cambian" involucrando a estudiantes de secundaria de diferentes escuelas públicas de la ciudad. La variedad de estos proyectos educacionales es notable: exposiciones, proyectos arquitectónicos, diseño de objetos, planes maestros para un barrio, documentales, caminatas. CUP facilita intersecciones. Con elementos de crítica institucional, estética relacional y activismo, su quehacer apunta a desmitificar lo inalcanzable y opaco y a producir inclusión. En sus propias palabras, "estimular la apreciación, comprensión y democratización del mundo material”. CUP cuenta con el apoyo de un amplio grupo de colaboradores, tanto instituciones como individuos, para implementar sus programas en distintos contextos. Con cada proyecto crece la red de relaciones, y por ende los potenciales educadores ${ }^{2}$. El objetivo es producir puentes, capacitación y participación en un sistema flexible; la idea es expandir la sala de clases, o más bien entender la sala de clases como una red de relaciones. Una idea fundamental es activar la relación entre

\section{The city as school}

\author{
Francisca Benítez Architect, Universidad de Chile
}

How many possibilities do architects have for acting in the urban realm? The experience of this Chilean woman in NY is far more than designing buildings. It is all about developing a communicative code to start a participative, engaged dialogue between architects and citizens: this time, high school students speak.

"The Chilean high school students have made us live a new May like the one from 1968 in Paris that shook the whole old Europe. Every so often is the youth that sets the note. Today the rebellion of the 'penguins' alters positively everybody's comfortableness. What has been contained for so long had to explode at some point; a catharsis that puzzles the Government, the teachers, every type of authority, political parties and unions. Everyone has been surpassed"1.

INTERSECTIONS, WEBS AND PARASITE EDUCATIONAL SYSTEMS / New York, May 31, 2006. While I write these lines, thousands of students throughout Chile carry out one of the most extraordinary mobilizations I have witnessed online. In spite of their young age, these students remind us of that promise that we keep on making to ourselves as a society, and they tell us it's about time to start fulfilling it.

In spite of the distance and the differences that separate Brooklyn and Chile, I am interested in looking at what they could have in common pointing to what the students have demonstrated in the organization of this national strike: the latent power in the existing infrastructure, the use of systems foreign to education to revitalize education itself, and the implications of webs and connections, beyond the internet and cyberspace and back to physical space.

This article attempts to contribute to the debate making reference to the superposition of educational programs of experimental and practical nature over the existing educational program, using the city as a textbook. These operations also indicate a way for architects to get involved in these processes.

Since 2001, I collaborate with the Center for Urban Pedagogy (CUP) in projects of education, art and architecture. This is an independent non profit organization, located in Brooklyn, New York. Its leaders, Damon Rich and Rosten Woo, plus an extensive and fluid network of collaborators, make "educational projects about places and how they change". These educational projects can be an exhibition, an architecture project, the design of an object, a master plan for a neighborhood, a documentary, a walk. CUP facilitates intersections. With elements of institutional critique, relational aesthetics and activism, its projects aim to demystify the unattainable and opaque and to produce inclusion, "to stimulate appreciation, understanding and democratization of the material world". CUP has built the support of a diverse group of collaborators, both institutions and individuals, to implement its programs in different contexts. With each exhibition the network of relations grows, therefore the potential for more educators ${ }^{2}$. The objective is to produce bridges, education and participation in a flexible system. The idea is to expand the classroom. In other words, to understand the classroom as network of relations. To activate the relationship between education and the existing cultural patrimony present in the immediate surroundings such as the street the neighborhood and the city, and also in museums, libraries, media and other institutions. 


\begin{abstract}
1 Carlos Poblete Ávila, profesor de Estado del Liceo Industrial Benjamín Franklin. 31 de mayo de 2006, http://liceobenja.blogspot com. Este era uno dentro de las decenas de blogs que apareciero en internet durante el paro estudiantil de mayo en Chile; a través de ellos los estudiantes dialogaron y coordinaron esfuerzos a través de todo el territorio nacional.

2 Para una completa nómina de organizaciones involucradas con
\end{abstract}

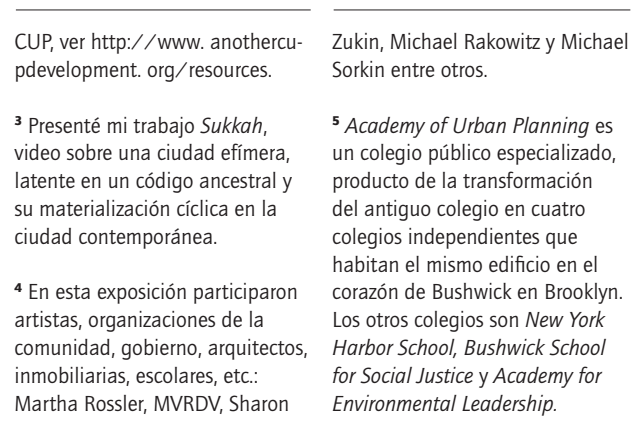

CUP, ver http:// www. anothercu- Zukin, Michael Rakowitz y Michael pdevelopment. org/resources. latente en un código ancestral ación cíclica en la

esta exposición participa Martha Ross
${ }^{5}$ Academy of Urban Planning es blico especializado antiguo colegio en cuatio

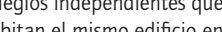
corazón de Bushwick en Brookly Los otros colegios son New York for Social Justice y Academy for Environmental Leadership.

\section{Poblete Avila, Carlos. Teacher, Benjamin Franklin Industria High School. May 312006. http://liceobenja. blogspot. $\mathrm{com} /$ This is one of the hundreds of blogs that appeared during the students strike on the Internet. Through these blogs the students dialogued and coordinated efforts through the national territory. \\ ${ }^{2}$ For a complete list of organiza- tions involved with CUP projects,}

\section{see http:// www.anothercupde- velopment.org/resources. \\ ${ }^{3}$ I presented Sukkah, a video about an ephemeral city latent in an ancestral code that material- izes and superimposes ittsef cycly- cally on the contemporary city. ${ }^{4}$ This exhibition included the work of artists, community and government organizations, architects, developers, youth, etc. Among them were Martha Rossler}

MVRDV, Sharon Zukin, Michael Rakowitz and Michael Sorkin.

${ }^{5}$ The Academy of Urban Planning is a specialized public school, the result of the transformation of the old school into four independent schools that inhabit the same building in the heart of Bushwick in Brooklyn: the other schools the New York Harbor School the Bushwick School for Social, the Bushick School for Social Justice, Leadership. la educación y el patrimonio cultural existente, tanto en el entorno inmediato (la calle, el barrio y el distrito) como en museos, bibliotecas, medios de comunicación y otras instituciones metropolitanas.

El trabajo está siempre teñido por una mirada desprejuiciada, humor e ingenuidad; los proyectos muchas veces parten de una pregunta simple. ¿A dónde va a parar toda la basura que producimos en Nueva York? Como respuesta, Garbage problems, un documental de $50 \mathrm{minu}$ tos hecho por un grupo de 7 jóvenes, analiza en profundidad el problema. Escrito, filmado, dirigido y editado por ellos mismos, explica de manera gráfica a través de entrevistas con políticos, empresarios, activistas y medioambientalistas, visitas a terreno y diagramas animados los procesos en cuestión. El documental fue estrenado en el Anthology Film Archives, junto con una exposición de propuestas de los estudiantes proponiendo usos alternativos para el vertedero en desuso, y con un panel de discusión, moderado por ellos mismos, con autoridades y especialistas. Todo esto, a cine lleno.

¿PoR QUÉ EL ESTUDIO DE LA CIUDAD? / La ciudad es un texto viviente. En ella está escrito todo: la historia, el sistema económico, las relaciones sociales, la política, los sistemas de creencias, la ideología imperante y más. Todo aquello que puede ser muy complejo de abordar de manera abstracta se vuelve visible y asible; en otras palabras, es posible implementar una educación cívica que relaciona los lugares que habitamos a diario con los abstractos sistemas que le dan forma. "Partiendo por el hecho de que las pirámides de Egipto fueron construidas por esclavos, los estudiantes necesitan examinar las dinámicas de poder relacionadas a la construcción y desarrollo de la propiedad. Los alumnos se benefician al entender por qué los edificios en su entorno son de la manera que son, tienen la forma que tienen y cuál es la lógica que los hace existir" (Damon, 2004).

Mi primera colaboración con CUP fue en mayo de 2001, cuando me uní a Storefront for Art and Architecture. En ese momento CUP estaba organizando la exposición Códigos de construcción: la ciudad programable, y me invitó a participar ${ }^{3}$. Esta era una muestra interdisciplinaria cuyo objetivo era entablar un diálogo entre grupos de intereses marcadamente distintos ${ }^{4}$ en torno a la regulación y construcción de la ciudad. El montaje se estructuró en torno a 8 edificios-mueble-maqueta-diagrama-soporte representando 8 cuerpos legales que rigen a la ciudad de Nueva York, más los aportes y distintos puntos de vista de los diferentes participantes. Códigos de construcción: la ciudad programable era un componente de un proyecto mayor, que además comprendía una exposición en la vitrina del Lower East Side Tenement Museum, una serie de caminatas, un ciclo de cine, paneles de discusión y talleres para jóvenes.

UN PRIMER ACERCAMIENTO A LA ARQUITECTURA / En 2005, CUP implementó un taller de arquitectura de 10 sesiones para jóvenes de 15 años, en el colegio Academy of Urban Planning 5 en Brooklyn. Los organizadores me invitaron a formular y guiar el taller, considerando como objetivos la integración entre los alumnos y su barrio o comunidad, además de la producción de documentos arquitectónicos: dibujos, planos, maquetas, etc.

En mi primera visita exploratoria me di cuenta que la tarea no sería fácil. Pasando el detector de metales penetré esta seudo fortaleza (con policías rondando los pasillos) en la búsqueda de un terreno para intervenir dentro del colegio. Encontré una especie de espacio residual producto
The work this always permeated by humor and a certain naivety. The projects start off with a simple question. Where does all the garbage we produce in New York City go? The answer to this question is Garbage Problems, a 50-minute documentary written, directed, filmed and edited by a group of 7 teenagers where the issue is analyzed extensively. The piece is composed of site visits, interviews with politicians, business owners, activists and environmentalists and contains animated diagrams to explain the processes involved. The documentary was first shown at the Anthology Film Archives, along with an exhibition of the authors' proposals for alternative uses of Fresh Kills, the garbage dump in disuse, and with a panel discussion -moderated by the teens themselves- with local authorities and specialists in front of a large audience packing the theater. WHY THE STUDY OF THE CITY? / The city is a living text, in her everything is written: history, the economic system, social relations, systems of belief, the prevailing ideology, and more. Anything that might be hard to approach given its abstract nature becomes visible and within reach, in other words, civic education that links the places in which we spend our everyday lives to the complex and abstract systems that shape them. "Starting from the fact that the Egyptian pyramids were built by slaves, the students need to examine the power dynamics of building and of property development. The students benefit from understanding why the buildings in their own neighborhoods look and function the way they do" (Damon, 2004).

Our first collaboration was in May 2001, when I joined Storefront Art and Architecture. At that moment CUP was organizing the exhibition Building Codes: The Programmable City and invited me to participate ${ }^{3}$. It was an interdisciplinary exhibition whose objective was to produce a dialogue between different interest groups ${ }^{4}$ around the regulation and construction of the city. The show was structured around 8 buildings-furniture-scale model-diagram-support representing 8 legal bodies which norm the built environment of New York City, plus the contributions and different points of view from the diverse participants. Building Codes: The Programmable City was one component of a greater plan, composed of a window exhibition in the Lower East Side Tenement Museum, a series of walks, a film series, panel discussions and youth workshops.

A FIRST APPROACH TO ARCHITECTURE MATTERS / In 2005 CUP implemented a 10 sessions architecture workshop for 15 year-old students at the Academy of Urban Planning 5 . CUP invited me to formulate and to implement the workshop considering integration between students and their neighborhood/community and producing architectural documents (drawings, plans, scale models, etc.) as main objectives. In my first exploratory visit I realized that the task would not be easy. I passed the metal detector and I penetrated this pseudo fortress (the police even walking through the corridors) looking for a site for our project. I found a residual space product of the layout of the tennis court 20 feet off the property limit: an area of $20 \times 100$ feet, in the corner, covered with grass and with two shipping containers on it. That was the place within the school limits where you could feel outside the school. Despite the fence, there was a direct relation with the corner deli, the Chinese take-out food store and the streets, Irving and Putnam. After an introductory class organized around an eclectic slideshow, we went on a site visit. The students organized themselves in groups of 5, and proceeded to do a survey. We 


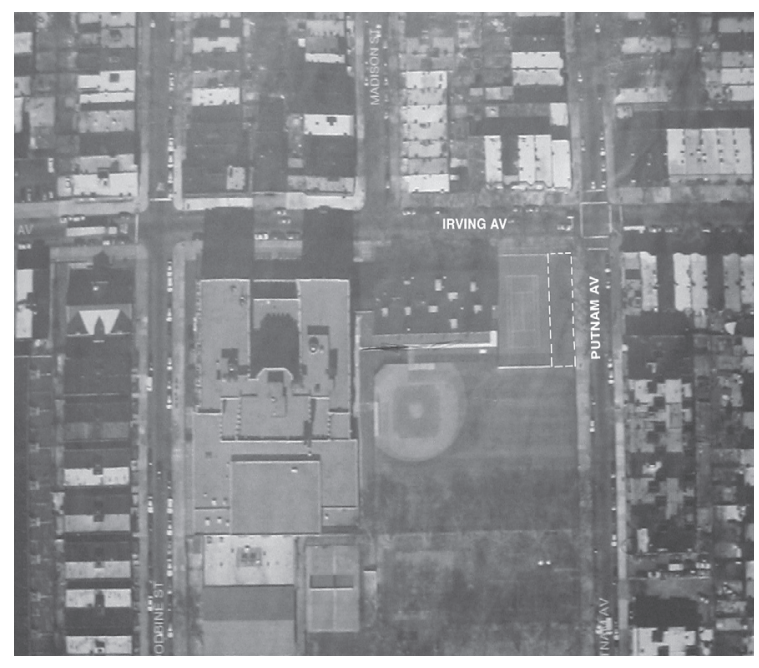

01

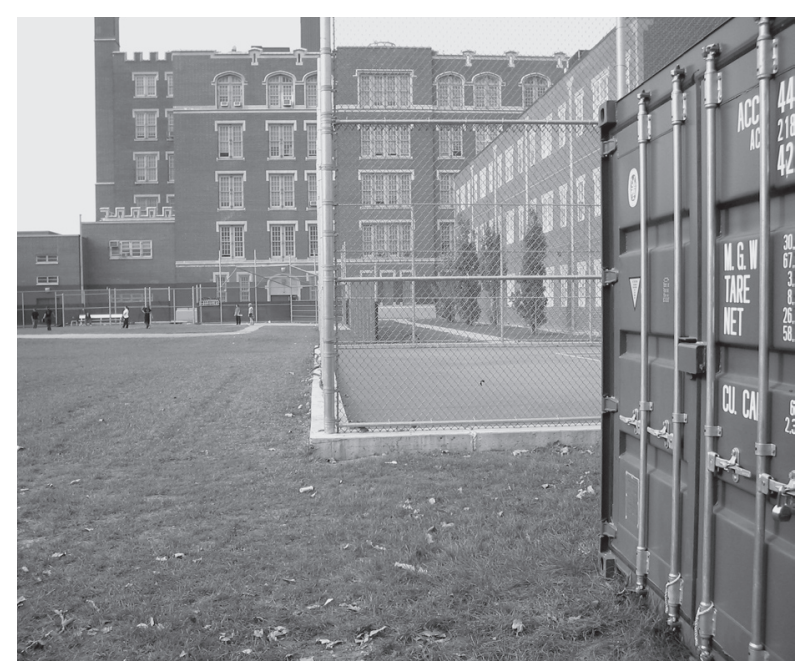

02

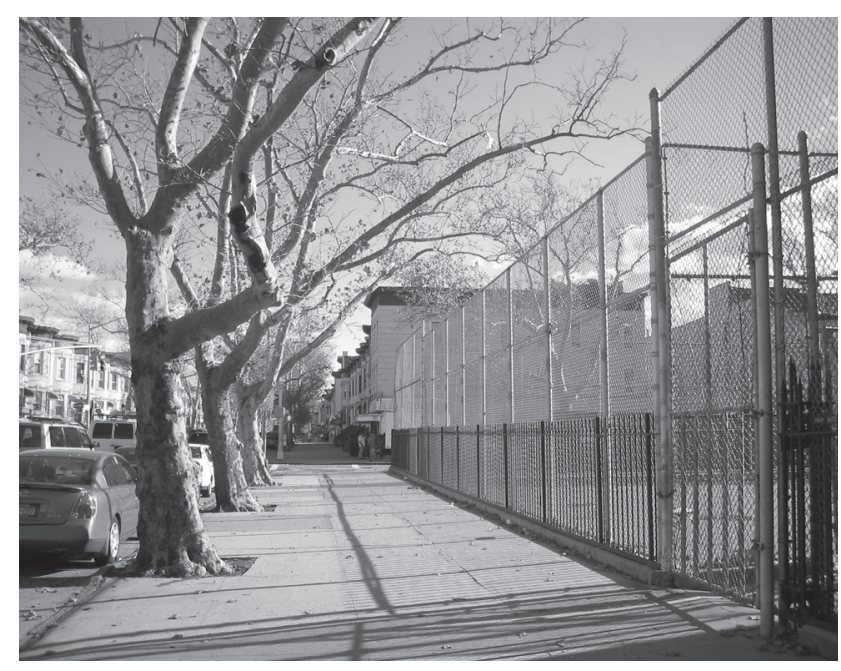

del trazado de una cancha de tenis a $6 \mathrm{~m}$ del límite del predio: un área de 6 por $30 \mathrm{~m}$ en la esquina, cubierta de pasto y con dos contenedores posados en ella. Ése era el lugar con un vínculo a la ciudad: a pesar de estar enrejado, había una directa relación con el deli de la esquina, el take-out de comida china y las calles Irving y Putnam.

Luego de una primera clase introductoria organizada en torno a un ecléctico diaporama, fuimos a visitar el terreno. Los alumnos se organizaron en grupos de cinco; no teníamos huinchas de medir por lo que ocupamos nuestro cuerpo. Cada grupo eligió al integrante cuyo pie (parte del cuerpo) fuera más cercano a un pie (unidad de medida). Hicimos una planta esquemática anotando medidas, materialidad, elevaciones de las fachadas próximas al predio, usos de suelo, tipos de vegetación existente, etc. Hablamos de escala, límites, conexiones, visibilidad, materialidad, relaciones visuales y funcionales; del barrio, de la calle, del recinto deportivo, etc. Luego les pedí que soñaran. Les pedí que olvidaran la mayor cantidad de restricciones e imaginaran qué les gustaría crear en ese lugar. Al principio las respuestas fueron tan predecibles como uniformes. La más popular: “iun MacDonald's!!”; la de risas nerviosas: “un invernadero para cultivar hierba”. A medida que el taller fue avanzando sus propuestas empezaron a aparecer, las ideas, los proyectos, los esquemas, dibujos y hasta las maquetas. A pesar de algunos episodios de crisis disciplinaria (materiales de maqueteo transformados en proyectiles voladores), hubo alumnos y proyectos notables. Un grupo propuso un edificio esquina rematado por un curioso personaje cara de bola con audífonos: cancha de bowling en el primer nivel -con un gran ventanal en forma de corazón hacia la calle- y un estudio de grabación en el segundo nivel. Una alumna creó un edificio de terapia psicológica, que tomó la forma de una esfera con dos escaleras de acceso, una desde la calle y otra desde el prado del colegio. Usando la planta circular para terapias grupales, dispuso en el segundo piso pequeños recintos perimetrales, fragmentados para consultas privadas ${ }^{6}$. Hubo un grupo que decidió agrandar el terreno dado para hacer una arena de lucha: "sencillamente, aquí nadie juega tenis, todos prefieren pelear... nuestro proyecto proveerá un lugar para que todos liberen esa necesidad". Otro grupo propuso un café al aire libre con una cubierta de lona, habilitando como baños los contenedores existentes en el sitio. Un grupo de alumnas sin mucho interés en participar optó por crear una dulcería e invirtió su tiempo en hacer maquetas de plasticina. Fue mejor dejarlas en paz, amasando absortas en su interminable plática. Otro grupo propuso un centro de juegos de video con cubierta geodésica.

SinERGÍAS EDUCACIONALES / La idea es generar sistemas educacionales parásitos que se insertan en estructuras mayores: un colegio, un museo o una asociación vecinal, que operan con cierta autonomía ${ }^{7}$ produciendo una relación activa, práctica y crítica con la realidad. En el contexto de un liceo o escuela esto complementa el trabajo de los profesores, les da un respiro y les enseña cosas nuevas a ellos también. Otra parte es la producción de intersecciones entre la escuela y otras instituciones y mecanismos; no pretendo abocar el desmantelamiento del sistema educacional como lo argumentara Ivan Illich en los setenta, si bien muchas de sus ideas en relación a estos temas parecen iluminadoras (Illich, 1971). Los profesores y pedagogos siguen a la cabeza del sistema educacional, pero su labor es asistida y complementada desde afuera, multiplicando los usos de infraestructuras existentes, fortaleciendo lazos y asumiendo la responsabilidad de educar colectivamente. Los más escépticos interpretarán estas experiencias como insigni- ficantes islas en un sistema capitalista despiadado, donde la educación queda a merced de la caridad o se transa como un bien de cambio más. Quizás se trata de una práctica modesta e incipiente, pero su capacidad de enriquecer la calidad de la educación está en su posible propagación rizomática, en todas direcciones y escalas: el carnicero del barrio que abre su carnicería para mostrarnos cómo disecta una vaca, la municipalidad que organiza discusiones del plan regulador con los liceos locales o el programa de televisión que incita a despertar y no a dormirse. ARQ

Bibliografía

Illich, Ivan. Deschooling society. Original de 1971. Marion Boyars Publishers, Londres, 1999. / Rich, Damon. "Learning to teach". Architecture magazine. VNU Business Publishing, Nueva York, febrero de 2004.

01 - 03 La situación de emplazamiento de Academy of Urban Planning. Brooklyn, Nueva York. El sitio contiguo a la cancha de tenis fue usado como emplazamiento para las propuestas de los estudiantes. 04 El taller de arquitectura CUP en Academy of Urban Planning. 05 - 06 Propuesta de pistas de bowling y estudio de grabación. 07 - 08 Pabellón para consejeros y terapia sicológica. 09 - 10 Propuesta de café al aire libre integrando containers existentes. "Tenemos la fantástica idea de convertir el campo al aire libre en un patio "Tenemos la fantástica idea de convertir el campo al aire libre en un patio de comidas donde la gente pueda reunirse. Nuestro patio de comidas será un punto de encuentro de la escuela, donde los profesores y alumnos podrá comer y compartir. Es un patio de comidas como de un mini-mall, pero justo aquí en la parte de atrás. Tendrá un baño hecho dentro de un container, dividido en dos para hombres y mujeres. El otro container se convertirá en un depósito de basura. El plan que hemos pensado es tener el puesto de comidas en un edificio nuevo, con segundo piso para los que quieran comer adentro. Hay una ventana vidriada para ver lo que pasa afuera; vamos a poner mesas con mini-quitasoles para dar un ambiente como de restaurante en una isla tropical. El pasto de la cancha dará el toque de naturaleza. Y no nos olvidemos de la lluvia: para cuando llueva, tenemos un toldo que va de lado a lado. Los estudiantes podrán tener a su disposición una gran variedad de comidas de diferentes culturas. Nadie que no sea de la escuela podrá entrar en los dominios del patio de comidas" 11 Puesto para venta de dulces 12 Cubierta geodésica para video juegos 


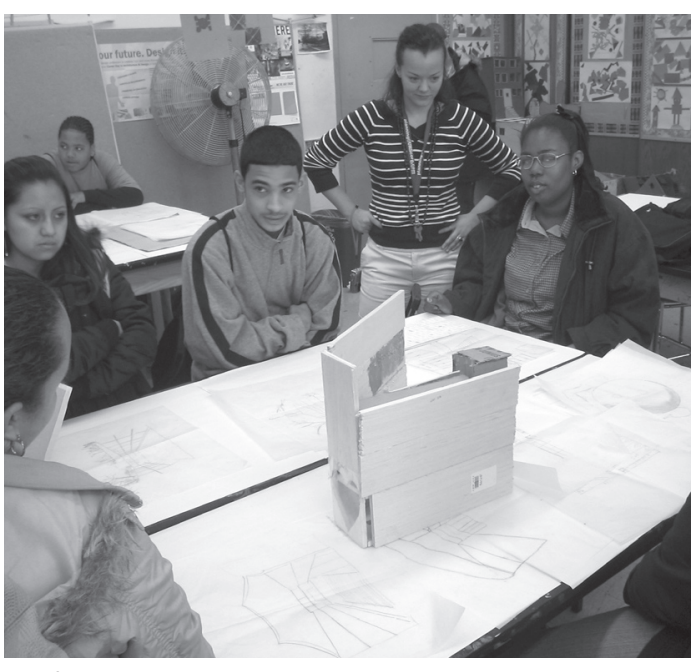

04

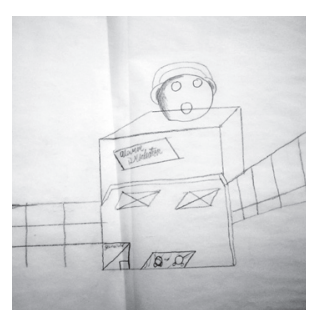

05

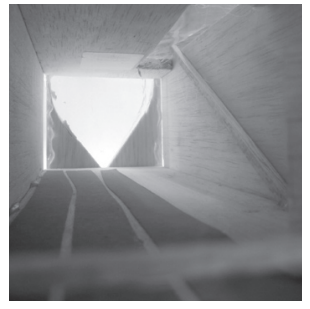

06

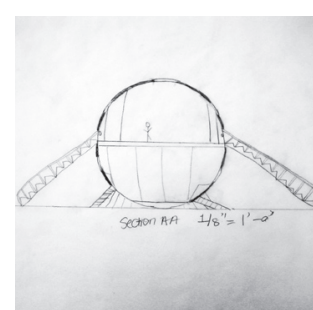

07

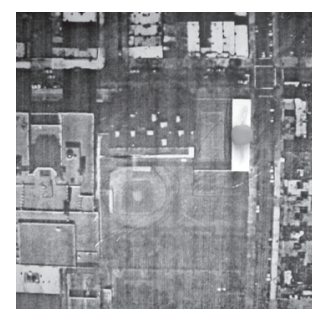

08

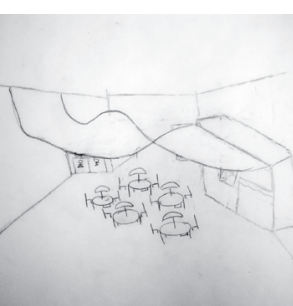

09

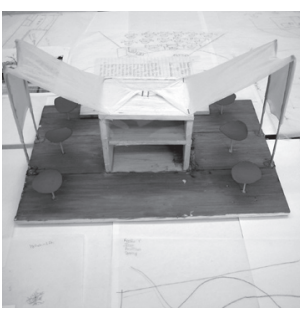

10

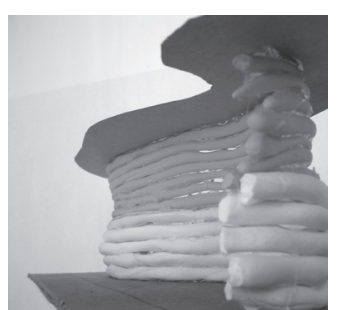

11



12 didn't have measuring tapes so we used our bodies: each group chose the big foot in the group whose foot (body part) was the closest to a foot (measure unit). We did schematic plans writing down measurements, materiality, elevations of the facades next to the site, land uses, types of existing vegetation, etc.

We spoke about scale, limits, connections, visibility, materiality, visual and functional relations, the neighborhood, the street, the sport field, etc. After that I asked them to dream, to forget about any restrictions and to imagine what would they like to create in that place. In the beginning the answers were as predictable as uniform, the most popular one: "a MacDonald's!!" the one of nervous laughter: "a greenhouse to cultivate grass". As the workshop developed, the dreams began to appear, the ideas, the projects, the schemes, the drawings and even the scale models. In spite of some moments of discipline crisis (model-making materials became flying projectiles) there were remarkable students. A group proposed a corner building crowned by a curious ball-face character with headphones: bowling alley on the first level -with a big heart-shaped window- and recording studio on the second level. A student created a Counseling building for psychological therapy in the form of a sphere ${ }^{6}$, with two access stairs, one from the street and another one from the meadow of the school, using the circular floor plan for group therapies, then in the second level fragmenting the space in small perimeter enclosures for private consultations. There was a group that decided to enlarge the given site to make an arena. "Simply put, nobody here plays tennis. Everybody prefers to fight. Our project provides a place for that need". Another group proposed an outdoor café, with a fabric canopy recycling the existing containers on the site to house the bathrooms. A group of students without much interest to participate chose to create a candy store and spent their time making play-do models. I left them be, in their endless chatting, their hands in the doe. Another group proposed a video games arcade covered by a geodesic dome.

EdUCATIONAL SYNERGIES / The idea is to generate parasite educational systems that are then inserted in greater structures such as a school, a museum, a neighborhood association, etc., and that operate with a certain degree of autonomy ${ }^{7}$, producing an active and practical relationship with reality. In the context of a school, this complements the work of the teachers, gives them a relief, and teaches them new things as well. I am not advocating the dismantling of the educational system like Ivan Illich did in the seventies, although many of his ideas in relation to these subjects seem quite illuminating to me (Illich, 1971). Teachers and pedagogy experts continue to be on top of the educational system, but their work is assisted and complemented from the outside, multiplying the uses of existing infrastructures, strengthening relationships and assuming the responsibility of education collectively. Skeptics will interpret these experiences as insignificant islands in a ruthless capitalist system where education is handled as a commodity or as charity. Maybe in their modest beginnings, but their power to strengthen society lies in their possible rhizomatic propagation and multiplication, all over the place and at every possible scale. From the local butcher who opens his shop to show us how he dissects a cow, or the municipality that organizes reviews of a master plan with local schools to the television program that makes us wake up, not fall asleep. ARo

\section{Bibliography}

Illich, Ivan. Deschooling society. Original from 1971. Marion Boyars Publishers, London, 1999. | Rich, Damon. "Learning to teach". Architecture magazine. VNU Business Publishing, New York, February 2004
6 En el diaporama introductorio no estaba el Cenotafio de Newto de Boullée, sino una imagen de la serie La casa del carbonero de Smiljan Radic, portada de $A R Q 39$, que creo se debe haber clavado en su subconsciente.

7 También trabajo en un taller de arte en vivienda social. Este es un proyecto municipal, del departamento de la vivienda (New York mento de la vivienda (New York City Housing Authority, NYCHA) para generar alternativas educacionales y recreativas extra-colegio quizás como respuesta y antídoto a la ghettoización producida por este tipo de vivienda, construida hace 40 años por NYCHA misma. Lo interesante de CUP es que por ser una organización pequeña no tiene la gravedad institucional de NYCHA, por lo tanto sus trabajos suelen ser bastante críticos. Las exposiciones realizadas en el programa de NYCHA pasan por la revisión -y en algunos casos censura- a diferencia de casos, censura a diferencia de CUP, que puede mantener una actitud irreverente. Ver el documental The Wever undergould documental Water Underground en http:/ www. anothercupdevelopment
org/ projects/ detail/ 35.
${ }^{6}$ The introductory slide show did not include Newton's Cenotaph by Boullée. It did include an image from Smiljan Radic's series The House of the Coal Man published in ARQ 39 that I think might have gotten fixed in her subconscious.

${ }^{7}$ I also work in a public housing art workshop. This it is a city project, administered by the New York City Housing Authority (NYCHA) to Housing Authority (NYCHA) to generate (n) atterschool alternatives, perhaps as an answer and antidote to the ghettoization produced by this type of housing project, built 40 years ago by NYCHA itself. What is interesting about CUP is that being a small, independent organization; it does not have the institutional gravity NYCHA has. The exhibitions presented by NYCHA are revised and sometimes even censored. CUP instead, given its operationat. flexibility, is able to keep an iexrevility, is able to keep an Underground project See The Water Underground project at http:// wh.anothercupdevelopment. org/projects/detail/35.

01 - 03 Academy of Urban Planning facilities. Brooklyn, New York. The site for the students projects was a peripheral area next to the tennis court. 04 Students of CUP architecture workshop at Academy of Urban Planning $05-06$ Bowling alley and recording studio.

$07-08$ Counseling building for psychological therapy

09 - 10 Outdoor café with fabric canopy and recycled containers "We have a fantastic idea to tum the open feld into a socializing food court Our have a fantastic idea to turn the open field into a socialling food court. Our food court is going to be a school hangout, where students and teachers can both eat and socialize. Its a minimall food court hangout, here at the back at the school. The food court's hangout will have a bathroom made out of a container, divided into two for men and women. The second container is going to be made into a garbage can. The plan we have set up is to have the food stand in a building. There is also a second floor if they want to eat inside. There is a glass window to view the outside. We are going to place tables with mini-umbrellas to give the feel of the island's restaurant's set up. The grass on the field will be used as a taste of nature. But, not forgetting the rain, because when it does we have a canopy, which will go from pole to pole. The students will be able to have a wide selection of foods from different cultures. No one from outside of the school will be allowed on the court's premises"

11 Puesto para venta de dulces

12 Geodesic dome for video game arcade 